УДК 621.865 .8

DOI 10.36461/NP.2020.54.1.020

\title{
МОДЕЛИРОВАНИЕ КИНЕМАТИКИ РАБОТЫ ШАРНИРНО-СТЕРЖНЕВОГО ГИДРОМАНИПУЛЯТОРА
}

\author{
Н. В. Бабоченко, канд. техн. наук, доцент; Антви-Вилсон Папа*, студент \\ Федеральное государственное бюджетное образовательное учреждение \\ высшего образования «Волгоградский государственный аграрный университет», \\ Россия, e-mail: nat-krivelskaya@mail.ru \\ *Управление гражданской авиации Ганы, г. Аккра, Республика Гана
}

В статье рассмотрена возможность определения кинематических параметров работы гидроманипуляторов, имеющих в качестве несущей конструкции шарнирно-стержневую стрелу. Конструкция шарнирно-стержневой стрелы имеет свои особенности, которые необходимо учитывать при проводимых расчетах. Особенно возникла сложность в определении параметров кинематики в работе гидроманипуляторов с такой конструкцией стрелы. Определение кинематических характеристик произведено разработанной на языке программирования $\mathrm{C}++$ программой. Она создавалась для использования на практике с целью облегчения процесса вычисления и выявления оптимальных значений работы стреловых гидроманипуляторов. Оригинальность описанной в статье программы подтверждена свидетельством о государственной регистрации программы для ЭВМ. Использование программы позволяет осуществлять выбор оптимальных значений кинематических характеристик и по полученным данным строить необходимые графики, тем самым облегчив исследовательскую работу по определению оптимальных значений работы гидроманипулятора с шарнирностержневой стрелой. Расчеты, с использованием компьютерной программы на языке программирования $\mathrm{C}++$, произведены для конструкторской разработки, оригинальность которой подтверждена патентом на полезную модель. С использованием компьютерной программы определили оптимальные кинематические параметры работы шарнирно-стержневой стрелы гидроманипулятора. При заданных величинах длин стержней, составляющих шарнирностержневое соединение стрелы гидроманипулятора, согласно работе компьютерной программы определяются координаты и углы поворота несущей конструкции шарнирнострежневой стрелы гидроманипулятора, а также скорость и ускорение её перемещения. По полученным данным возможно построение графиков, таких как изменение положения шарниров в пространственной системе координат, составляющих шарнирно-стержневое соединение стрелы гидроманипулятора, углов поворота и скоростей и т. д. Установлено, что программа работает, как подтверждают полученные результаты, для определения кинематических характеристик конкретной конструкторской разработки, а значит, возможно ее использование для расчетов параметров кинематики и других подобных конструкторских разработок, как, шарнирно-стержневой стрелой, так и стреловых гидроманипуляторов.

Ключевые слова: гидроманипулятор, шарнирно-стержневая стрела, компьютерная программа, язык программирования С++, координаты перемещения стрелы, кинематические характеристики работы гидроманипулятора.

\section{Введение}

Рассматривая возможность определения параметров кинематики в работе гидроманипуляторов, имеющих в качестве несущей конструкции шарнирно-стержневую стрелу, столкнулись со сложностью в проводимых расчетах. Создание новой конструкторской разработки гидроманипуляторов влечет за собой исследования кинематики работы. Проведя обзор литературы по определению параметров кинематики в работе гидроманипуляторов [1-12] и проанализировав его стало понятно, что определение характеристик кинематики работы шарнирно-стержневого гидроманипулятора- процесс, сопровождающийся громоздкими расчетами. Определение кинематических характеристик работы стреловых гидрманипуляторов довольно кропотливый процесс и требует больших затрат по времени расчета. Для упрощения расчетов и с учетом конструктивных особенностей несущих органов гидроманипуляторов разработаны и используются на практике компьютерные программы. Программы эти усовершенствуются с целью получения более точных характеристик требуемых величин, и, в зависимости от заданных и искомых 
параметров, имеем для каждой конструкторской разработки свою компьютерную программу.

Цель нашего исследования - рассмотрение возможности использования компьютерной программы на языке программи-

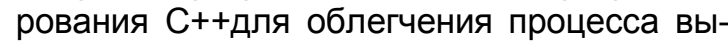
числения и выявления оптимальных значений работы шарнирно-стержневых гидроманипуляторов. Для выполнения поставленной цели использовали новую конструкторскую разработку шарнирно-стержневой стрелы гидроманипулятора, оригинальность которой подтверждена патентом РФ на полезную модель [1], и создали программу на языке программирования $\mathrm{C}++$, позволяющую определять параметры кинематики работы как шарнирно-стержневой стрелы, так и гидроманипулятора в целом. Оригинальность программы подтверждена свидетельством о государственной регистрации программы для ЭВМ [2]. Расчеты, проведенные с использованием компьютерной программы, дают возможность провести построение графиков, таких как изменения положения шарниров в пространственной системе координат, составляю- щих шарнирно-стержневое соединение стрелы гидроманипулятора, углов поворота, скоростей и ускорений, облегчая исследовательскую работу по определению оптимальных значений кинематики.

Методы и материалы

Используя компьютерные технологии и известные математические фоормы моделирования [1-14], нами была разработана модель кинематики работы шарнирно-стержневого гидроманипулятора, изложенная на языке программирования $\mathrm{C}++$, фррагмент которой представлен на рисунке 1.

Результаты

Для того, чтобы понять сложность в расчетах кинематики при работе шарнирно-стержневого гидроманипулятора, необходимо рассмотреть несущую конструкцию шарнирно-стрежневой стрелы гидроманипулятора (рис .2), которая содержит корневую секцию (1) и связанную с ней рукоять (2). Для подъема и разворота корневой секции и, следовательно, всей стрелы предусмотрены два силовых цилиндра (3) и (4). Эти цилиндры расположены под углом друг к другу, их штоки связаны посредством общего шарнира и соединены между

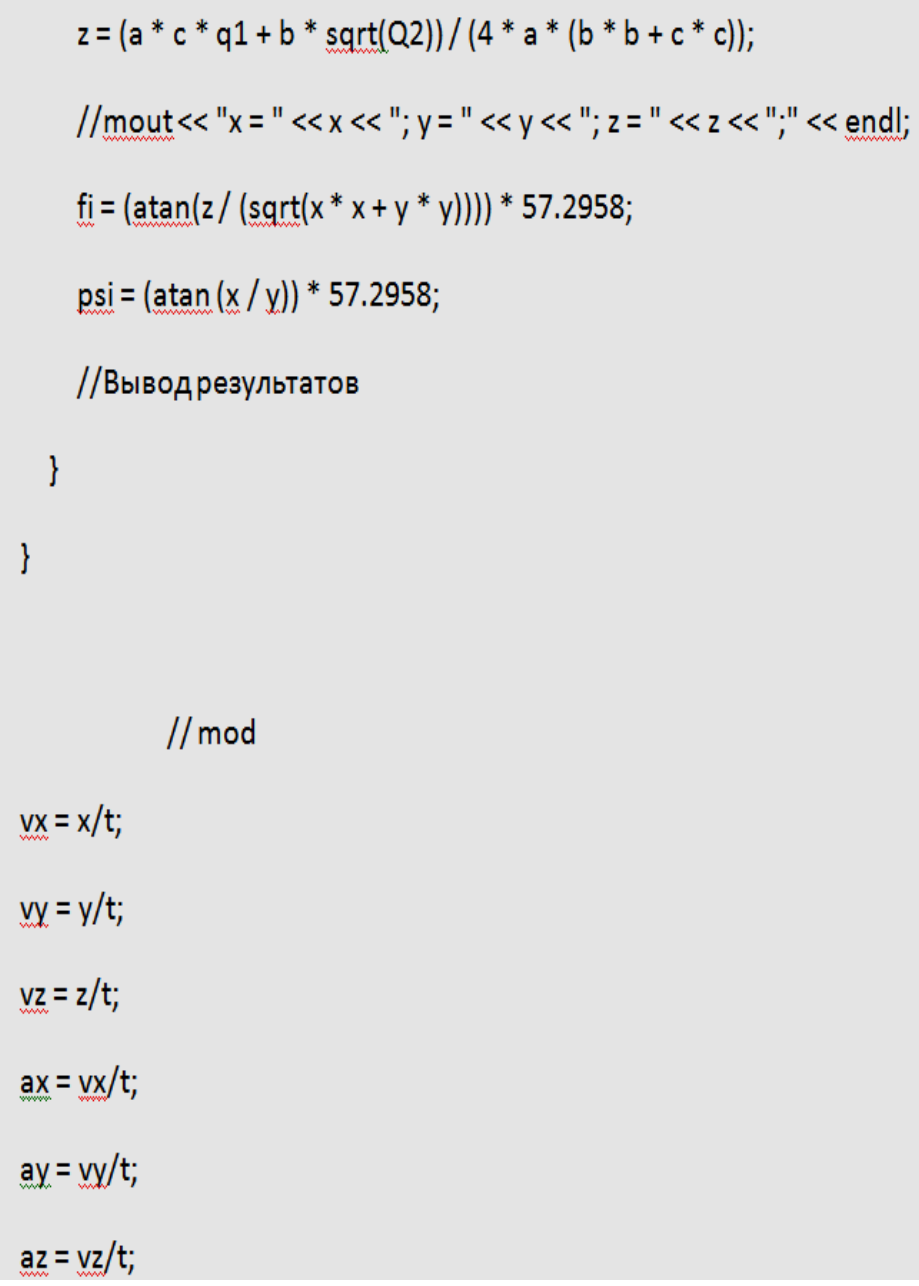

Puс. 1. Фрагмент компьютерной программы 
собой и со стрелой. Корневая секция (1) и противоположные концы (корпуса) цилиндров (3) и (4) закреплены на основании грузоподъемного средства посредством опорно-поворотных устройств с двумя степенями свободы. На цапфах шарнира шарнирно закреплены два стержня стержневых шарнирных треугольников рукояти, а также плоские в поперечном направлении фермы - посредством своих гнезд на каждом конце этих ферм. Фермы, выполняющие функции стержней, и гидроцилиндр (5) на виде сбоку образуют шарнирный, с двумя острыми углами, треугольник - корневую секцию. Вершины острых углов соединены с основаниями рукоятью (2), а вершина тупого угла связана с общим шарниром. Рукоять (2) выполнена из двух стержневых шарнирных треугольников с двумя острыми углами. Фермы, выполняющие функцию стержней, и гидроцилиндр (6), на виде сбоку, образуют один шарнирный треугольник рукояти (2). Второй стержневой шарнирный треугольник рукояти (2) образуют стержни со своими шарнирами, на виде сбоку. Общей связью двух стержневых шарнирных треугольников рукояти (2) является стержень, который шарнирно соединен со стержнями стержневых шарнирных треугольников. Два стержня стержневых шарнирных треугольников расположены параллельно друг другу. Общая связь двух стержневых шарнирных треугольников рукояти (2) и стержень выполнены в виде плоских в поперечном направлении ферм со своими гнездами для шарниров. Два стержня стержневых шарнирных треугольников параллельны друг другу являющиеся составной частью рукояти (2) стрелы, связаны со стержнями стержневых шарнирных треугольников и траверсой. В свою очередь, плоские в поперечном направлении фермы, выполняющие функцию стержней, связаны с траверсой посредством своих гнезд для шарниров на каждом конце этих ферм. С поверхностью траверсы связан выдвижной грузонесущий орган (7), который имеет возможность выдвигаться по направляющей на поверхности траверсы на величину, регулируемую работой гидроцилиндра (8). Благодаря такой конструкторской разработке достигается оптимальное распределение нагрузок растяжениясжатия на стержни и плоские фермы, способствующие повышению силовой мощности конструкции, а для грузонесущего органа сообщается дополнительное перемещение в горизонтальной плоскости, что расширяет функциональные возможности стрелы.

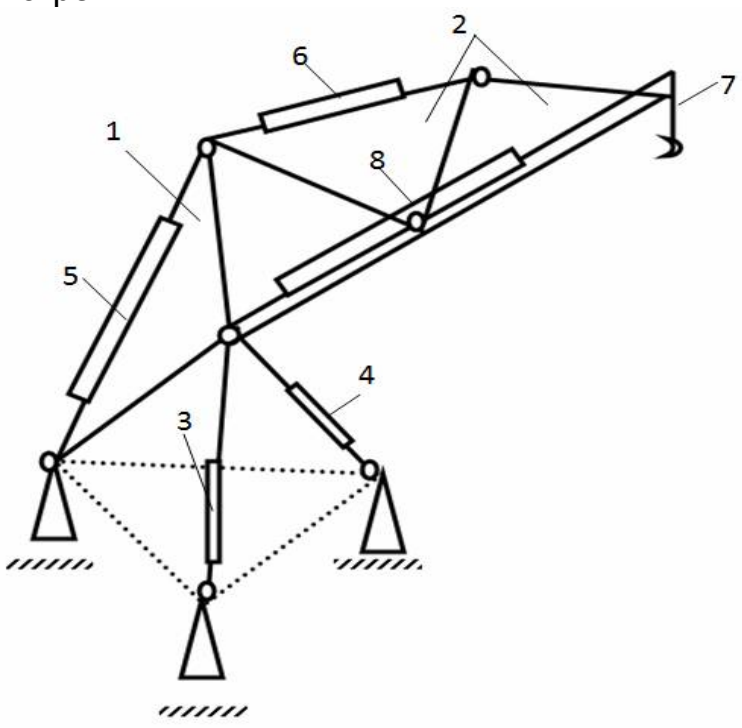

Pис. 2. Конструкция стрелы с шарнирно-стержневыми звеньями

При заданных величинах длин стержней, составляющих шарнирно-стержневое соединение стрелы гидроманипулятора, согласно работе компьютерной программы определяются координаты и углы поворота

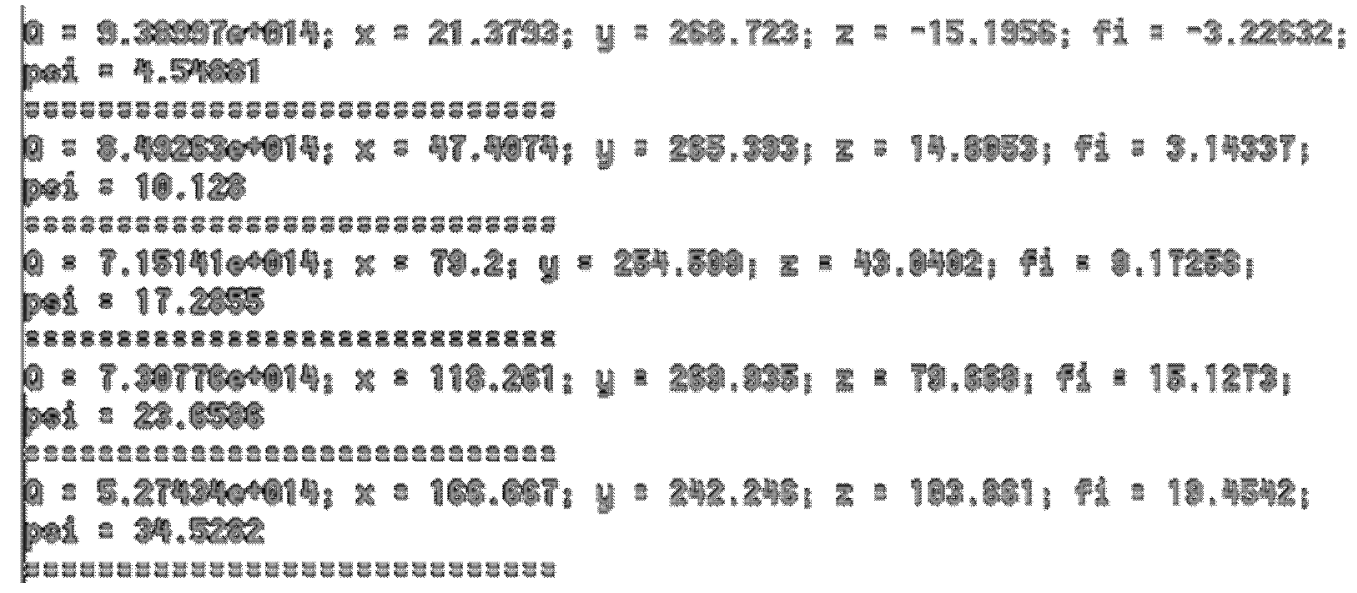

Puс. 3. Определение координат и углов поворота конструкции шарнирно-стержневой стрелы гидроманипулятора

Нива Поволжья $\quad$ № 1 (54) февраль 2020 


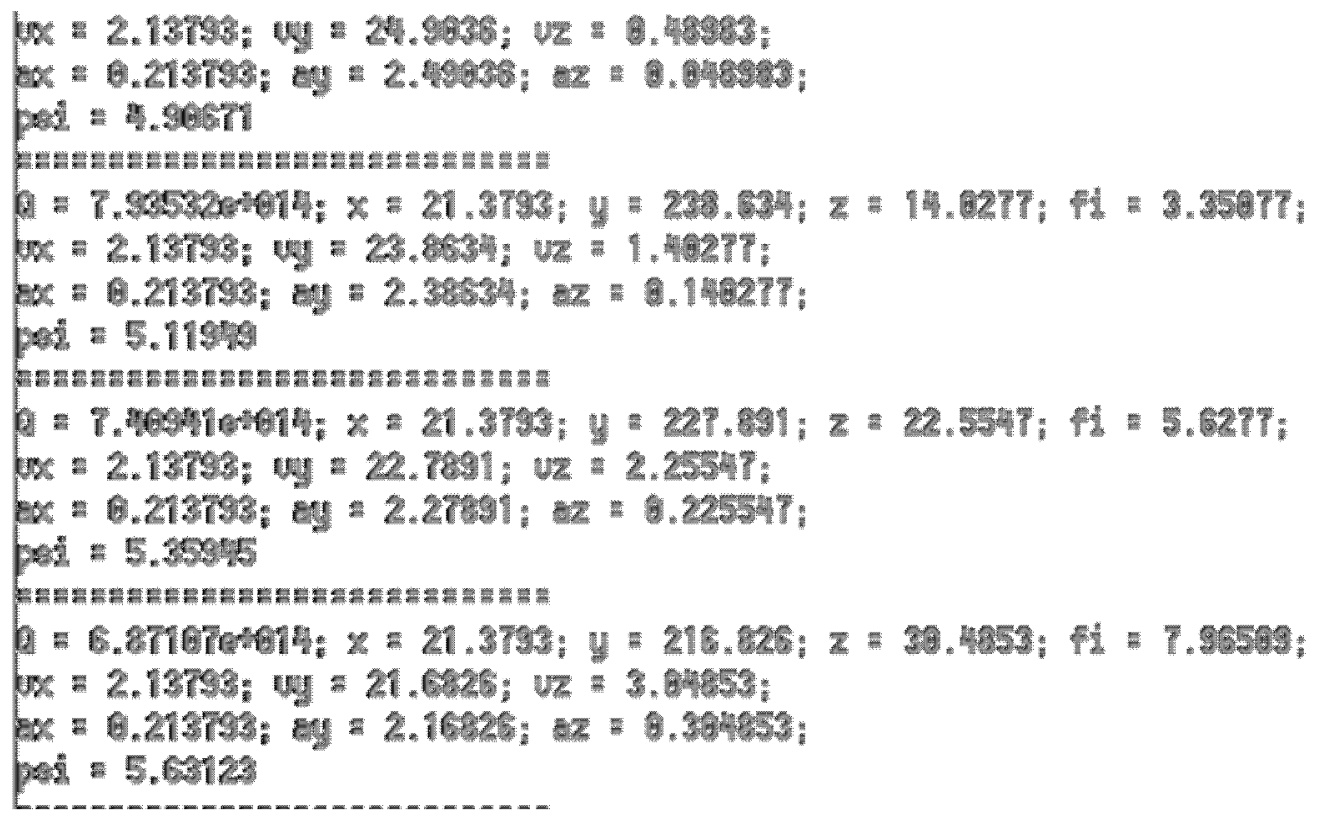

Puc. 4. Определение скорости и ускорения перемещения конструкции шарнирно-стержневой стрелы гидроманипулятора

несущей конструкции шарнирно-стрежневой стрелы гидроманипулятора (рис. 3), а также скорость и ускорение её перемещения (рис. 4).

Путем выполнения программы (рис. 3, 4) были получены необходимые данные для дальнейших исследований работы гидроманипулятора с шарнирно-стержневой стрелой. По полученным данным возможно построение графиков, таких как изменения положения шарниров в пространственной системе координат, составляющих шарнирно-стержневое соединение стрелы гидроманипулятора (рис. 5), углов поворота и скоростей (рис. 6, 7) и т. д.

В процессе работы программы возможно как осуществление выбора опти- мальных значений кинематических характеристик работы шарнирно-стержневого гидроманипулятора, так и по полученным данным построения необходимых графриков, тем самым облегчая исследовательскую работу по определению оптимальных значений.

\section{Заключение}

Определение кинематических характеристик возможно при использовании компьютерной программы, разработанной на языке программирования $\mathrm{C}++$. Согласно работе программы установлено, что полученные результаты подтверждают возможность использования данной программы для расчетов параметров кинематики шарнирно-стержневых гидроманипуляторов, а

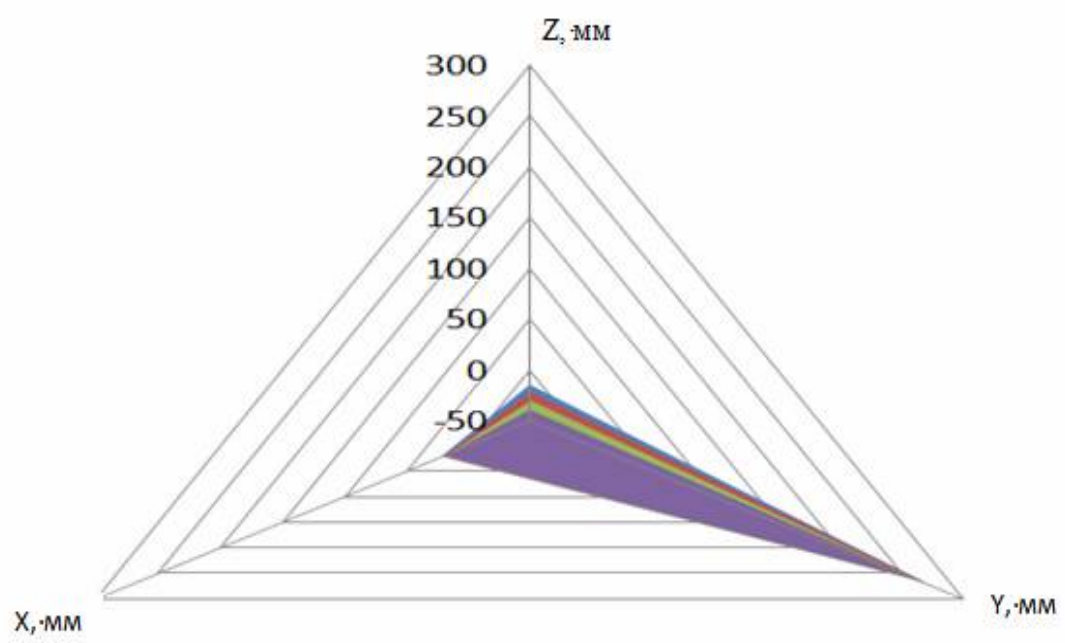

Puс. 5. Изменение положения шарниров в пространственной системе координат в зависимости от координат перемещения 


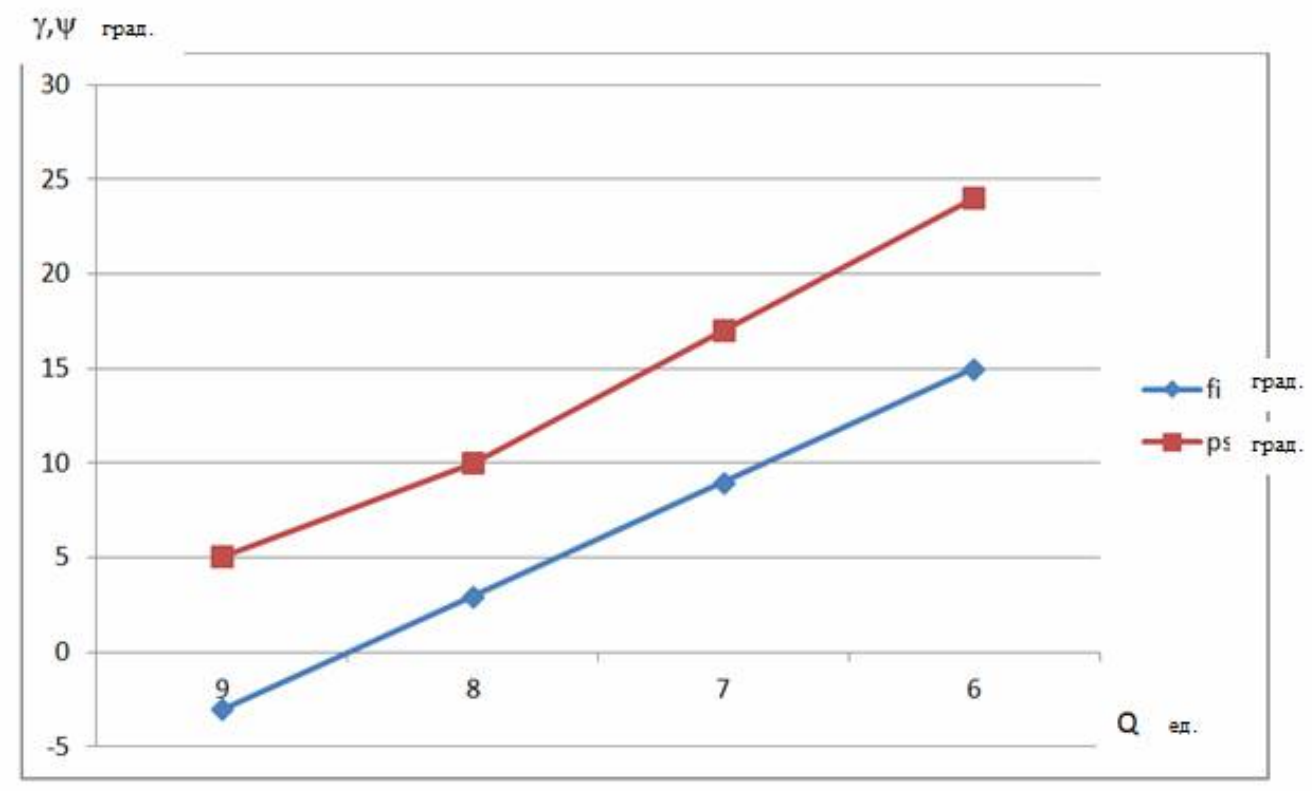

Рис. 6. Фрагмент графиков углов поворота

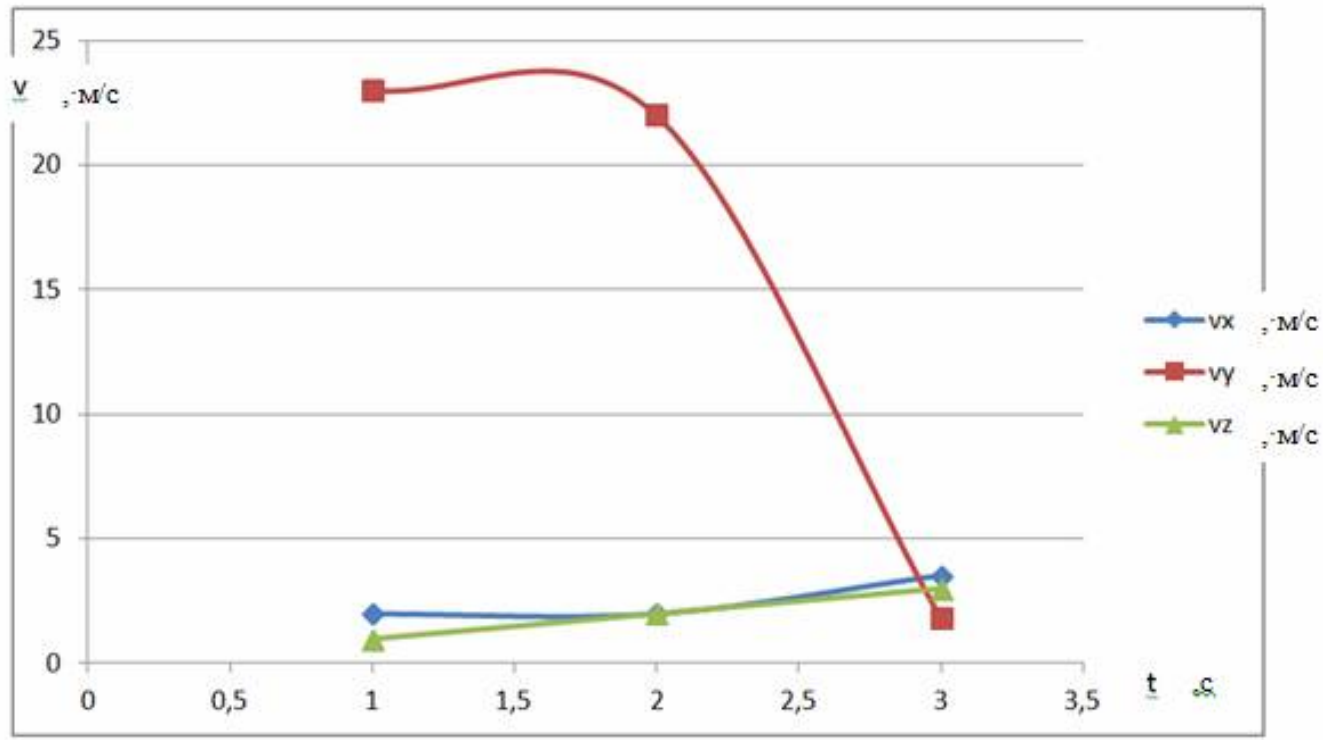

Puc. 7. Фрагмент графиков скоростей

значит, использование и для расчетов кинематики других подобных конструкторских разработок стреловых гидроманипуляторов. Используя программу, возможно осуществить выбор оптимальных значений кинематических характеристик работы шарнирно-стержневого гидроманипулятора, таких как углы поворота, скорость, ускорение перемещающейся в работе шарнирно-стержневой стрелы и по полученным данным простроить необходимые графики, тем самым облегчив исследовательскую работу по определению оптимальных значений.

\section{Лumepamypa}

1. Патент РФ на полезную модель № 165029. Стрела грузоподъёмного средства / Бабоченко Н. В. Опубл. 09.05.16 г. - 8 с.

2. Свидетельством о государственной регистрации программы для ЭВМ № 2018615414. Определение кинематических характеристик при работе шарнирно-стержневой стрелы манипулятора / Бабоченко Н. В. - Опубл.2018. - 11 с.

3. Бабоченко, Н.В. Программа для определения кинематических параметров шарнирностержневого робота-манипулятора / Н. В. Бобаченко// Современные научные исследования. 2016. - Приложение № 15. - Выпуск 5. - С.576-580. 
4. Доронин, Ф. А. Кинематика плоского манипулятора параллельной структуры с тремя степенями свободы в среде MATHCAD / Ф. А. Доронин //Теория механизмов и машин. - 2016. - № 1 . - C.6-20.

5. Лапиков, В. Н. Алгоритм решения прямой задачи кинематики многосекционного манипулятора параллельной структуры / В.Н.Лапиков, А. Л. Пащенко // Наука и образование. - 2014. № 2. - С.76-95.

6. Локтионов, А. В. Расчет кинематических параметров пространственных исполнительных механизмов / А. В. Локтионов // Механика. Научные исследования и научно-методические разработки. - 2014. - № 8. - С.106-120.

7. Пындак, В. И. Расширение функциональных возможностей гидроманипуляционных систем / В. И. Пындак, Н. С. Воробьева, И. А. Несмиянов // Известия нижневолжского агроуниверситетского комплекса. - 2015. - № 3. - С.227-231.

8. Пындак, В. И. Кинематические возможности погрузочных манипуляторов на базе пространственных механизмов / В. И. Пындак, Н. С. Воробьева, С. Д. Фомин // Известия нижневолжского агроуниверситетского комплекса. - 2016. - № 1. - С.190-195.

9. Расчет кинематических характеристик манипулятора при измененном угле между стрелой и рукоятью / Л. Т. Раевская, А. В. Швец, Ф. Ф. Дахнеев, Д. Т. Анкудинов // Современные проблемы науки и образования - 2013. - № 2. - С.57-83.

10. Соколов, А. В. Программные связи и обеспечение устойчивости движения электромеханического манипулятора / А. В. Соколов //Вестник Российского Университета дружбы народов. Серия: математика, информатика, физика. - 2014. - № 4. - С. 85-94.

11. Ширинкин, М. А. Разработка манипуляционного механизма параллельной структуры с четырьмя степенями свободы / М. А. Ширинкин, В.А.Глазунов, С. В. Палочкин // Известия высших учебных заведений. Технология текстильной промышленности. - 2010.- № 1. - С.102-107.

12. Zhang, T. Position/Force Control for a Single Leg of a Quadruped Robot in an Operation Space / T. Zhang, Q. Wei, H. Ma // International Journal of Advanced Robotic Systems. - 2013. - Vol. 10.

13. Hada, S. Simulation ofspatialkinetics / S. Hada, Y. Takeda, S. Hanagasaki // Proceeding of robotic symposia. - 2011. - № 6. - P. 89-100.

14. Bonev, I. A. Geometric Analysis of Parallel Mechanisms, thèse de doctorat / I. A. Bonev. - Québec: Université Laval, 2002.[Электронный ресурc]. URL: http://www.gpa.etsmtl.ca/prof/ibonev/Thesis Bonev. pdf.

UDC 621.865 .8

DOI 10.36461/NP.2020.54.1.020

\title{
MODELLING THE KINEMATICS OF A HINGED-ROD HYDRAULIC MANIPULATOR
}

\author{
N. V. Babochenko, Candidate of Technical Sciences, Assistant-professor; \\ Antvi-Wilson Papa*, student
}
Federal State Budgetary Educational Institution of Higher Education «Volgograd State Agricultural University», Volgograd, e-mail: nat-krivelskaya@mail.ru
${ }^{*}$ Ghana Civil Aviation Administration, Accra, Republic of Ghana

The article considers the possibility of determining the kinematic parameters of hydraulic manipulators that have a hinged-rod boom as a supporting structure. The design of the hinged-rod boom has its own features that must be taken into account when performing calculations. Especially there was a difficulty in determining the kinematic parameters during the operation of hydraulic manipulators with such a boom design. The kinematic characteristics were determined by a program developed in the $\mathrm{C}++$ programming language. It was created for practical use in order to simplify the calculation and identification of optimal values of the boom hydraulic manipulators operation. The originality of the program described in the article is confirmed by the certificate of state registration of the computer program. Using the program allows to select the optimal values of kinematic characteristics and build the necessary graphs based on the data obtained, thereby simplifying the research work of determining the optimal values of the hydraulic manipulator with a hinged-rod boom. Calculations, with the use of a computer program in the $\mathrm{C}++$ programming language, were made for engineering development, the originality of which is confirmed by a patent for a utility model. Using a computer program, the optimal kinematic parameters of the hinge-rod boom of the hydraulic manipulator were determined. 
According to the computer program, with the given values of the lengths of the rods constituting a hinge-rod connecting arm of the crane, the coordinates and angles of rotation of the supporting structure of the hinged-rod boom of the crane and also its velocity and acceleration of movement are determined. Based on the obtained data, it is possible to plot graphs, such as changes in the position of the hinges in the spatial coordinate system that make up the hinge-rod connection of the hydraulic manipulator boom, angles' rotation and velocity, etc. As the results confirm, the program works to determine the kinematic characteristics of a particular engineering development. It means that its use is possible for calculating the kinematic parameters of the other similar design developments, both the hinged-rod boom and boom hydraulic manipulators.

Keywords: hydraulic manipulator, hinge-rod boom, computer program, C++ programming language, coordinates of the boom movement, kinematic characteristics of the hydraulic manipulator operation.

\section{References:}

1. Russian patent for utility model no. 165029. The boom of the hoisting appliance / Babochenko N. V. Publ. 09.05.16- p. 8.

2. Certificate of state registration of the computer program no. 2018615414. Determination of kinematic characteristics in the operation of the hinged-rod boom of the manipulator / Babochenko N. V. - Publ. 2018. - p. 11.

3. Babochenko, N. V. Program for determining the kinematic parameters of a hinged-rod robot manipulator / N. V. Babochenko // Modern scientific researches. - 2016. - Appendix 15. - Issue 5. P. 576-580.

4. Doronin, F. A. Kinematics of a plane manipulator of a parallel structure with three degrees of freedom in MATHCAD / F. A. Doronin // Theory of mechanisms and machines. -2016 . - No. 1. - P. 6-20.

5. Lapikov, V. N. Algorithm for solving the direct kinematics problem of a multi-section manipulator of parallel structure / V. N. Lapikov, A. L. Pashchenko // Science and education. - 2014. - No. 2. P. 76-95.

6. Loktionov, A. V. Raschet kinematicheskih parametrov prostranstvennyh ispolnitelnyh mekhanizmov / A. V. Loktionov // Mehanika. Nauchnye issledovaniya i nauchno-metodicheskie razrabotki. 2014. - No. 8. - P. 106-120.

7. Pyndak, V. I. Enhance of hydraulic manipulator systems' functionality / V. I. Pyndak, N. S. Vorobiyova, I. A. Nesmiyanov // Izvestiya nizhnevolzhskogo AUK. - 2015. - No. 3. - P. 227-231.

8. Pyndak, V. I. Kinematic capabilities of loading manipulators based on spatial mechanisms / V. I. Pyndak, N. S. Vorobiyova, S. D. Fomin // Izvestiya nizhnevolzhskogo AUK. - 2016. - No. 1. P. 190-195.

9. Calculation of the kinematic characteristics of the manipulator at a changed angle between the boom and the handle / L. T. Raevskaya, A. V. Shvets, F. F. Dahneev, D. T. Ankudinov // Modern problems of science and education - 2013. - No. 2. - P. 57-83.

10. Sokolov, A. V. Program communications and assurance the stability of the movement of the electromechanical manipulator / A. V. Sokolov // RUDN Journal. Studies in: mathematics, computer science, physics. - 2014. - No. 4. - P. 85-94.

11. Shirinkin, M. A. Razrabotka manipulyatsionnogo mekhanizma parallelnoj struktury s chetyrmya stepenyami svobody / M. A. Shirinkin, V. A. Glazunov, S. V. Palochkin // Izvestiya vysshih uchebnyh zavedenij. Tekhnologiya tekstilnoj promyshlennosti. - 2010. - № 1. - P. 102-107.

12. Zhang, T. Position / Force Control for a Single Leg of a Quadruped Robot in an Operation Space / T. Zhang, Q. Wei, H. Ma // International Journal of Advanced Robotic Systems. - 2013. Vol. 10.

13. Hada, S. Simulation of spatial kinetics / S. Hada, Y. Takeda, S. Hanagasaki // Proceeding of robotic symposia. - 2011. - № 6. - P. 89-100.

14. Bonev, I. A. Geometric Analysis of Parallel Mechanisms, thèse de doctorat / I. A. Bonev. Québec: Université Laval, 2002. [Электронный ресурc]. URL:// http://www. gpa. etsmtl. ca/prof/ibonev/ThesisBonev. pdf. 